\title{
Use of Firewood Ash Waste in Electrical Siliceous Porcelain
}

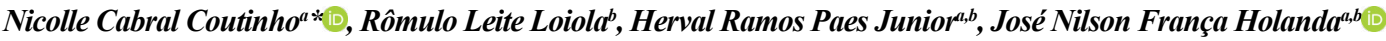 \\ ${ }^{a}$ Programa de Pós-Graduação em Engenharia e Ciência dos Materiais - PPGECM, Universidade \\ Estadual do Norte Fluminense Darcy Ribeiro - UENF, Campos dos Goytacazes, RJ, Brasil \\ ${ }^{b}$ Laboratório de Materiais Avançados - LAMAV/SEMMA, Universidade Estadual do Norte Fluminense \\ Darcy Ribeiro - UENF, Campos dos Goytacazes, RJ, Brasil
}

Received: December 12, 2018; Revised: May 12, 2019; Accepted: June 18, 2019

\begin{abstract}
The use of firewood ash waste for the production of electric porcelain can represent an important technological and environmental alternative for the final disposal of this abundant solid waste material. This work aims to study the effect of replacing of sodium feldspar (albite) for firewood ash waste in electrical siliceous porcelain formulation. The firewood ash waste was obtained from a ceramic plant located in south-eastern Brazil (Campos dos Goytacazes-RJ). For this purpose, siliceous porcelain formulations containing up to $4.2 \mathrm{wt} . \%$ of firewood ash waste as a replacement for sodium feldspar were prepared. Disk specimens were pressed and fired at $1300{ }^{\circ} \mathrm{C}$ using a fast-firing cycle. The porcelain specimens were tested to determine their technical properties (linear shrinkage, water absorption, apparent porosity, apparent density, tensile strength, and electrical resistivity). The results indicated that test specimens containing up to $4.2 \mathrm{wt} . \%$ of firewood ash waste have high potential for use as electrical siliceous porcelain material. Thus, an alternative use of firewood ash waste is proposed, which can be converted into economic gain and also contribute for the environmental sustainability.
\end{abstract}

Keywords: Firewood ash, solid waste, siliceous porcelain, properties.

\section{Introduction}

It is well known that pollutant industrial solid wastes have become a serious problem for environmental sustainability worldwide. In addition, the final disposal of industrial solid waste in a sustainable way is considered a complex and expensive issue. For this reason, the use of solid waste is increasing in many industrial sectors, including the ceramic sector for production of several ceramic materials ${ }^{1,2}$. In the ceramic sector the conventional raw materials could be partially or totally replaced by industrial solid wastes promoting environmental sustainability. However, in order to be considered as an alternative raw material, the solid waste must be carefully characterized so that its behavior during processing and its effects on the final products are foreseen $^{3,4}$.

The ceramic industry of the Campos dos Goytacazes-RJ region uses firewood as the main source of fuel in the process of firing its ceramic products. A further question arises to be solved by companies with the by-product of the combustion of firewood called firewood ash waste. Such firewood ash wastes generated in large scale have been mainly disposed of inappropriately or stored in landfills, resulting in economic and environmental problems. For this reason, these solid wastes have been characterized and used all over the world, not only to avoid being deposited in landfills, but also to cause benefits such as $\mathrm{pH}$ adjustment of agricultural soils $\mathrm{s}^{5,6}$. In addition to this, firewood ash wastes have also been tested for the manufacture of ceramic products ${ }^{7-9}$.
Triaxial porcelain is one of the most widely studied types of ceramic materials. It consists mainly of clay, quartz and feldspar, and has several applications, among them, electrical insulation material ${ }^{3}$. Due to their complexity, porcelain materials are still researched and developed. Therefore, there are still significant challenges regarding the understanding of porcelains in relation to raw materials, processing, phases and microstructural evolution ${ }^{10,11}$.

Porcelain is called "siliceous" if quartz is used as filler and "aluminous" if bauxite or alumina is used for this purpose ${ }^{12}$. Electrical siliceous porcelain is mainly used for the production of low voltage insulators and in telecommunications engineering. These elements do not need high mechanical strength, but need to demonstrate high durability and reliability ${ }^{13}$. Due to the high costs of manufacturing process of porcelain by using pure raw materials, these have become less attractive for applications such as electrical insulators, while some materials such as polymers, glasses and composites have been considered low-cost alternative to electrical insulation. Thus, research on reducing the production costs of porcelain insulators is an urgent task for companies ${ }^{14}$. In this context, the use of solid wastes to produce electrical porcelain materials has been tested ${ }^{15-17}$. However, the use of firewood ash waste in the production of electrical siliceous porcelain has not yet been investigated.

The main objective of this work was to investigate the possibility of incorporation of firewood ash waste as partial substitute of sodium feldspar in siliceous porcelain bodies, to be used as electrical insulation material. 


\section{Materials and Methods}

In this study, siliceous porcelain formulations containing up to $4.2 \mathrm{wt} \%$ of firewood ash waste were prepared (Table 1). The raw materials used were plastic clay, kaolin, quartz, sodium feldspar and firewood ash waste generated during the firing process of red ceramic products. Kaolin, quartz and sodium feldspar are commercial raw materials, with a particle size of less than $45 \mu \mathrm{m}$. The samples of plastic clay and firewood ash waste were collected at Arte Cerâmica Sardinha, Campos dos Goytacazes-RJ, Brazil. The plastic clay and firewood ash waste were dried in an oven at $110^{\circ} \mathrm{C}$ for $24 \mathrm{~h}$, dry-ground in a ball mill, and then sieved to the desired particle size $(<45 \mu \mathrm{m})$. The standard formulation of siliceous porcelain (formulation M0) used as reference is composed of plastic clay (29 wt.\%), kaolin (25 wt.\%), quartz (25 wt.\%) and sodium feldspar (21 wt.\%). In the other formulations, sodium feldspar was partially replaced by firewood ash waste (Table 1). The chemical composition of the raw materials was determined by X-ray fluorescence (Phillips, PW2400). The mineralogical analysis was performed by X-ray diffraction (XRD-7000, Shimadzu) with $\mathrm{Cu}-\mathrm{K} \alpha$ radiation at a scanning speed of $1.5^{\circ}(2 \theta) / \mathrm{min}$. ICDD-JCPDS cards were used to identify the mineral phases.

All porcelain formulations (Table 1) were mixed, homogenized and microgranulated through the dry process. The porcelain formulations were moistened with 7 wt.\% of water and pressed into a steel mold, such as disk specimens $(25 \mathrm{~mm}$ in diameter and $10 \mathrm{~mm}$ in height), under uniaxial pressing at $50 \mathrm{MPa}$. After the conformation, the specimens were dried at $110{ }^{\circ} \mathrm{C}$ for $24 \mathrm{~h}$ and fired at $1300{ }^{\circ} \mathrm{C}$ in a laboratory electrical kiln (FSQC-1300/3 model, Maitec), by using a fast-firing cycle $(<60 \mathrm{~min})$.
The following technical properties of the fired specimens were determined: water absorption, apparent porosity, apparent density, linear shrinkage, tensile strength, and electrical resistivity. The water absorption values were obtained from the mass differences between the saturated specimens and heated with water (immersed in boiling water for $2 \mathrm{~h}$ ), according to ASTM C 373-72. The apparent porosity of the specimens was calculated according to the standard ASTM C 373/94-88. The apparent density was measured by the Archimedes method. The values of linear shrinkage were evaluated from the variation of the diameter of the disk specimens. The mechanical strength of the fired specimens was determined in terms of tensile strength by using an universal test machine (Instron model 5582). The crossbar speed was held at $0.5 \mathrm{~mm} / \mathrm{min}$.

The volume electrical resistivity measurements were determined by using a digital multimeter with configuration for 2-wire Ohms measurements (3458A model, Agilent Technologies). The two conductive plates involving the test specimens were painted with silver conductive ink and cured at $120{ }^{\circ} \mathrm{C}$ for $10 \mathrm{~min}$. All electrical measurements were carried out at room temperature.

\section{Results and Discussion}

The chemical compositions of the raw materials are given in Table 2. The results indicated the higher presence of silicon oxide $\left(\mathrm{SiO}_{2}\right)$, except in the firewood ash waste sample. It can also be seen that the firewood ash waste sample contains a high amount of fluxing oxides, mainly calcium oxide (41.59 wt.\% of $\mathrm{CaO}$ ) and high loss on ignition (35.15 wt.\%). This result is in agreements with chemical composition data of firewood ash waste found in literature ${ }^{7,8}$. Thus, firewood ash waste as a partial substitute for sodium feldspar has a high potential to influence the densification behavior of electrical siliceous porcelain formulation.

Table 1. Siliceous electrical porcelain compositions.

\begin{tabular}{lccccc}
\hline \multirow{2}{*}{ Formulations } & \multicolumn{2}{c}{ Clays (wt.\%) } & \multicolumn{2}{c}{ Fluxes (wt.\%) } & Quartz (wt.\%) \\
\cline { 2 - 5 } & Clay & Kaolin & Feldspar & Ash & 25.00 \\
\hline M0 & 29.00 & 25.00 & 21.00 & 0.00 & 0.00 \\
M1 & 29.00 & 25.00 & 19.95 & 1.05 & 25.00 \\
M2 & 29.00 & 25.00 & 18.90 & 2.10 & 25.00 \\
M3 & 29.00 & 25.00 & 17.85 & 3.15 & 25.00 \\
M4 & 29.00 & 25.00 & 16.80 & 4.20 & 15.00 \\
\hline
\end{tabular}

Table 2. Chemical composition of the raw materials (wt.\%).

\begin{tabular}{|c|c|c|c|c|c|c|c|c|c|c|c|}
\hline & $\mathrm{SiO}_{2}$ & $\mathrm{Al}_{2} \mathrm{O}_{3}$ & $\mathrm{CaO}$ & $\mathrm{Fe}_{2} \mathrm{O}_{3}$ & $\mathrm{~K}_{2} \mathrm{O}$ & $\mathrm{MgO}$ & $\mathrm{MnO}$ & $\mathrm{Na}_{2} \mathrm{O}$ & $\mathrm{P}_{2} \mathrm{O}_{5}$ & $\mathrm{TiO}_{2}$ & ${ }^{*} \mathrm{LOI}$ \\
\hline Plastic clay & 43.39 & 31.06 & 1.15 & 3.86 & 0.78 & 0.43 & $<0.04$ & 0.25 & 1.07 & 1.31 & 16.66 \\
\hline Kaolin & 49.07 & 33.74 & 0.30 & 0.22 & 1.97 & 0.061 & - & 0.52 & - & $<0.01$ & 14.01 \\
\hline Quartz & 98.97 & 0.41 & $<0.01$ & $<0.01$ & 0.18 & $<0.01$ & - & 0.13 & - & 0.019 & 0.26 \\
\hline Feldspar & 69.55 & 18.82 & 0.17 & 0.14 & 1.47 & 0.09 & - & 9.63 & - & 0.017 & 0.32 \\
\hline Ash waste & 1.76 & 1.40 & 41.59 & 1.06 & 7.28 & 6.96 & 0.50 & 1.63 & 2.57 & 0.10 & 35.15 \\
\hline
\end{tabular}

"LOI: loss on ignition. 
The mineral phases of the raw materials identified by X-ray diffraction are given in Table 3 . The siliceous porcelain formulations are mainly composed of kaolinite $\left(\mathrm{Al}_{2} \mathrm{O}_{3} \cdot 2 \mathrm{SiO}_{2} \cdot 2 \mathrm{H}_{2} \mathrm{O}\right)$, quartz $\left(\mathrm{SiO}_{2}\right)$, albite $\left(\mathrm{NaAlSi}_{3} \mathrm{O}_{8}\right)$, and calcium carbonate $\left(\mathrm{CaCO}_{3}\right)$. These results are in agreement with the chemical composition data (Table 2). As expected, commercial kaolin, quartz, and sodium feldspar are mainly composed of kaolinite, quartz and albite, respectively. The plastic clay sample is mainly composed of kaolinite with gibbsite, goethite, mica and quartz as accessory minerals. Such a mineral composition is typical of red clays from the Campos dos Goytacazes-RJ region ${ }^{18}$. The firewood ash waste sample presented a complex mineral composition with calcium carbonate in form of calcite $\left(\mathrm{CaCO}_{3}\right)$ as major mineral phase. This is in accordance with the literature ${ }^{19}$.

The water absorption of the fired specimens is shown in Figure 1. Water absorption is a physical property used in technical standards to specify ceramic products for various applications. Electrical porcelains, in particular, shall have a maximum water absorption value equal to $0.5 \%{ }^{20}$. The fired specimens whose composition had substitution of sodium feldspar for firewood ash waste showed adequate water absorption to be considered as porcelain. This reduction in the water absorption values can be due to the great presence of fluxing oxides $(\mathrm{CaO}, \mathrm{MgO}$, and $\mathrm{K}_{2} \mathrm{O}$ ) in the chemical composition of the firewood ash waste, which aid in the formation of higher quantity of liquid phase during the firing process. In addition, the presence of firewood ash waste tends to cause a decrease on the viscosity of the glassy phase formed. Similar behavior can be observed in the apparent porosity of the specimens (Figure 2). The decrease in the apparent porosity of electrical porcelain pieces may be due to their higher densification and lower open porosity.

The apparent density of the fired siliceous porcelain specimens is shown in Figure 3. As can be observed, the fired specimens presented apparent density values ranging from 2.24 to $2.39 \mathrm{~g} / \mathrm{cm}^{3}$, which are adequate for production de electrical siliceous porcelains. In fact, the siliceous porcelains with density values ranging from 2.20 to $2.40 \mathrm{~g} / \mathrm{cm}^{3}$ are appropriated to be used as low-voltage insulator ${ }^{20,21}$. The results also showed that the porcelain specimens with higher amount of firewood ash waste (4.20 wt.\%) in the composition had lower apparent density, which may be due to the closed porosity caused by the formation of gas bubbles inside them ${ }^{22-24}$. This result indicates that the replacement of sodium feldspar with firewood ash waste in electrical siliceous porcelain formulations is limited.

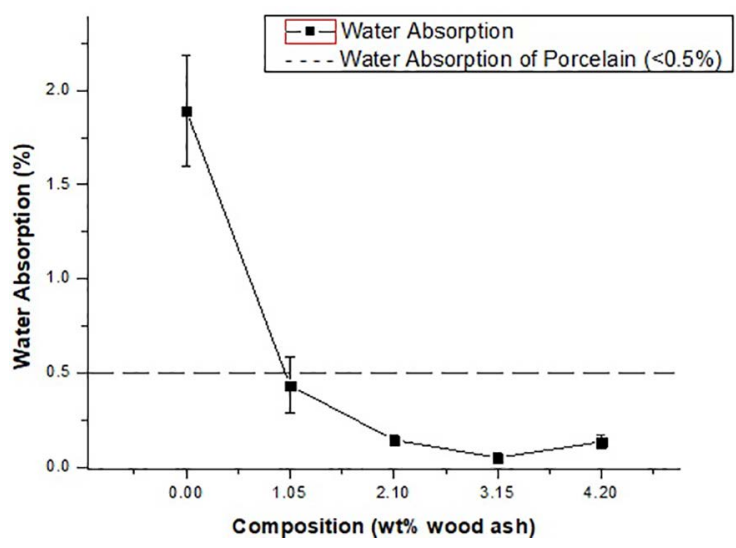

Figure 1. Water absorption of the fired siliceous porcelain pieces.

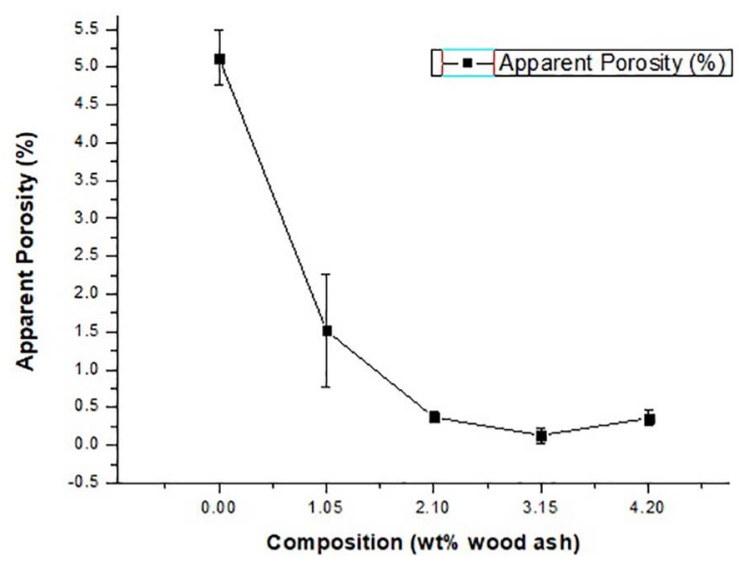

Figure 2. Apparent porosity of the fired siliceous porcelain pieces.

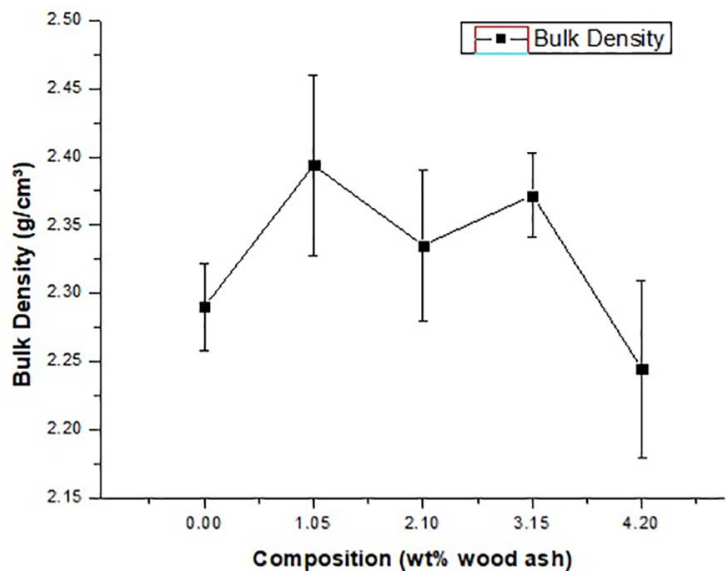

Figure 3. Apparent density of the fired siliceous porcelain pieces.

Table 3. Mineral phases identified in the raw materials.

\begin{tabular}{ll}
\hline Raw Material & Mineral Phases \\
\hline Plastic Clay & Kaolinite $^{+}$, gibbsite, goethite, mica and quartz \\
Kaolin & Kaolinite $^{+}$, mica and quartz \\
Quartz & Quartz $^{+}$ \\
Feldspar & Albite $^{+}$and quartz \\
Ash waste & Cordierite, calcium carbonate \\
\hline
\end{tabular}


Figure 4 shows the diametral linear shrinkage of the fired specimens. The values of diametral linear shrinkage in the range between 8.72 and $10.30 \%$ are suitable for the production of electric porcelain. However, the use of higher amount of firewood ash waste $(4.20 \mathrm{wt} . \%)$ caused a reduction in the linear shrinkage of the fired specimens. This may be due to the swelling of the fired specimens caused by the formation of gas bubbles inside them. This is in agreements with the results of apparent density.

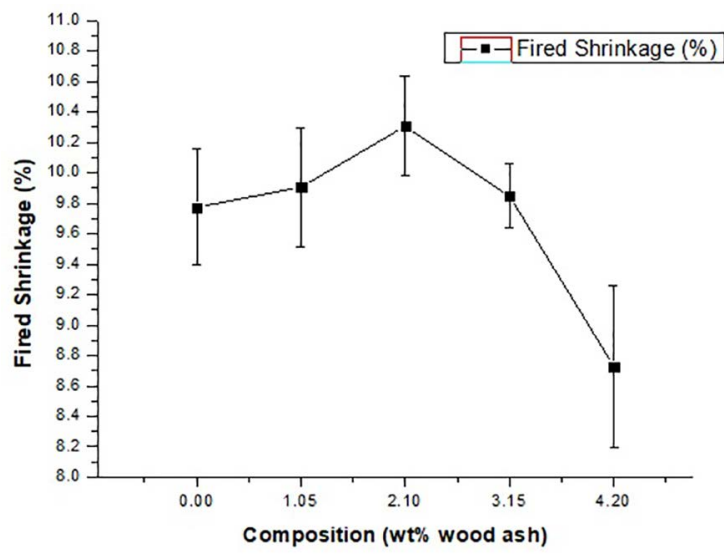

Figure 4. Linear shrinkage of the fired siliceous porcelain pieces.

Figure 5 shows the tensile strength of the fired specimens. In this work the mechanical strength of the fired specimens was evaluated in terms of tensile strength due to the sample geometry (cylindrical disk). The siliceous porcelain specimens produced presented values of tensile strength within the 11.27 - 13.73 MPa range. The results also showed that it is not possible to establish a correlation of the tensile strength with the amount of added firewood ash waste. In fact, as seen in Figure 5, a variation in tensile strength within the dispersion limits occurred.

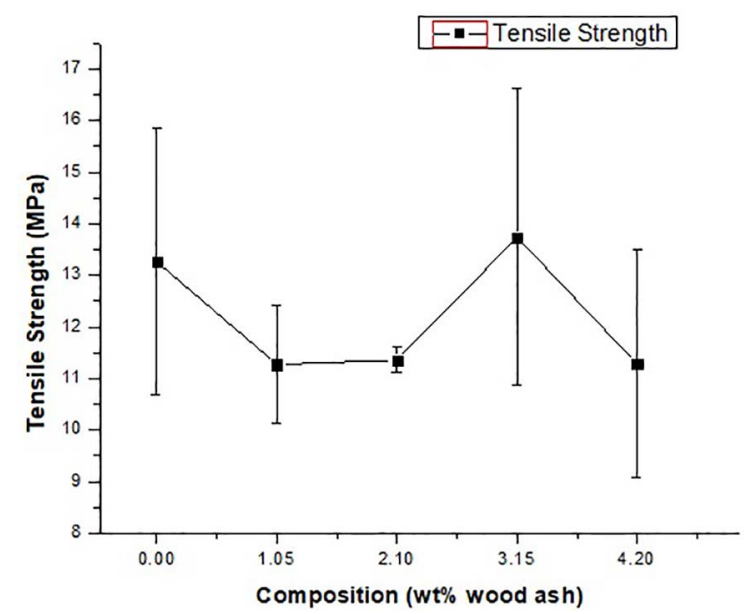

Figure 5. Tensile strength of the fired siliceous porcelain pieces.
The volume electrical resistivity values of the fired specimens are shown in Figure 6. Note that the specimens fired by using a fast-firing cycle presented high values of volume electrical resistivity $\left(\left(\sim 1.0-4.7 \times 10^{9} \Omega . \mathrm{m}\right)\right.$ typical of electrical siliceous porcelains ${ }^{20}$. The electrical resistivity of the siliceous porcelain specimens showed an increase with the addition of firewood ash waste. This effect is mainly related to the change in the composition of the glassy phase, which is modified due to the presence of firewood ash waste in the siliceous porcelain formulations. Higher amount of glassy phase of lower viscosity was probably formed during the firing process. According with the literature ${ }^{25,26}$, the increases in the electric resistivity of porcelain specimens is connected mainly with the change in the composition and viscosity of the glassy phase, namely, with a change in the content of fluxing oxides. Thus, siliceous porcelain specimens with partial substitution of sodium feldspar for firewood ash waste can be considered as a good electrical insulation material.

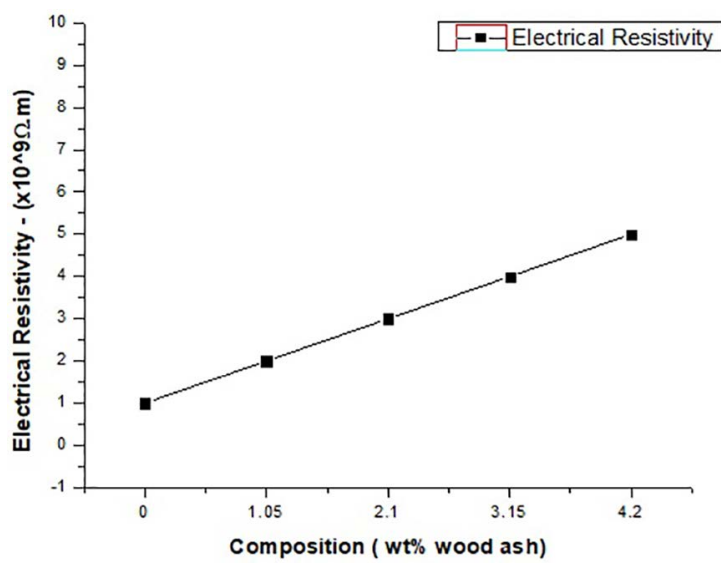

Figure 6. Electrical resistivity of the fired siliceous porcelain pieces.

\section{Conclusions}

The firewood ash waste used in this work is rich in fluxing oxides, such as $\mathrm{CaO}, \mathrm{K}_{2} \mathrm{O}$, and $\mathrm{MgO}$, and therefore has high potential to be used as an alternative flux material for sodium feldspar (albite) in siliceous porcelain formulations. The addition of firewood ash waste affects the composition of the glassy phase and technical properties of the fired specimens. It was found that the firewood ash waste positively influenced the volume electrical resistivity of the siliceous porcelain specimens. The results suggest that electrical siliceous porcelains containing up to $4.20 \mathrm{wt} . \%$ of firewood ash waste with good technical properties could be produced at $1300{ }^{\circ} \mathrm{C}$ by using a fast-firing cycle. Thus, the incorporation of firewood ash waste into electric siliceous porcelain formulations can be a favorable alternative to the environment and ceramic industry. 


\section{Acknowledgements}

This study was financed in part by the Coordenação de Aperfeiçoamento de Pessoal de Nível Superior - Brasil (CAPES) - Finance Code 001; Foundation for Research Support of the State of Rio de Janeiro - Brasil (FAPERJ) - Process No. E-26/203.013/2016; and National Council for Scientific and Technological Development - Brasil (CNPq) - Process No. 305928/2016-3). The authors also thank the Arte Cerâmica Sardinha by the supply of the firewood ash waste.

\section{References}

1. Andreola F, Barbieri L, Lancelloti I, Leonelli C, Manfredini $\mathrm{T}$. Recycling of industrial wastes in ceramic manufacturing: State of art and glass case studies. Ceramics International. 2016;42(12):13333-13338.

2. Daigo I, Kiyohara S, Okada T, Okamoto D, Goto Y. Element-based optimization of waste ceramic materials and glasses recycling. Resources, Conservation and Recycling. 2018;133:375-384.

3. Bhattacharja S, Evanko JL, Gajda J, Carty RH. Utilization of Illinois fly ash in manufacturing of ceramic tiles. Technical Report. Zhengzhou: Zhengzhou Minevik Heavy Industry Science and Technology; 1999.

4. Lee WE, Boccaccini R, Labrincha JA, Leonelli C, Drumond CH III, Cheeseman CR. Green engineering-ceramic technology and sustainable development. American Ceramic Society Bulletin. 2007;86(2):20-28.

5. Augusto L, Bakker MR, Meredieu C. Wood ash applications to temperate forest ecosystems - potential benefits and drawbacks. Plant and Soil. 2008;306(1-2):181-198.

6. Omil B, Piñeiro V, Merino A. Soil and tree responses to the application of wood ash containing charcoal in two soils with contrasting properties. Forest Ecology and Management. 2013;295:199-212.

7. de Medeiros ENM, Spoto RM, Neves GA, Menezes RR. Incorporação de cinza de lenha, lodo de estação de tratamento de água e cinza de casca de arroz em massa cerâmica. Utilização da técnica de planejamento. Cerâmica. 2010;56(340):399-404.

8. Pereira SI, Petersson M, Zaccaron A, Nandi VS, Fernandes P. Incorporação de cinza do eucalipto em massa de cerâmica vermelha. Revista Eletrônica de Materiais e Processos. 2016;11(2):68-72.

9. Kizinievic O, Kizinievic V. Utilisation of wood ash from biomass for the production of ceramic products. Construction and Building Materials. 2016;127:264-273.

10. Dana K, Das S, Das SK. Effect of substitution of fly ash for quartz in triaxial kaolin-quartz-feldspar system. Journal of the European Ceramic Society. 2004;24(10-11):3169-3175.
11. Serra MF, Conconi MS, Suarez G, Aglietti EF, Rendtorff NM. Volcanic ash as flux in clay based triaxial ceramic materials, effect of the firing temperature in phases and mechanical properties. Ceramics International. 2015;41(5 Pt A):6169-6177.

12. Carter CB, Norton MG. Ceramic Materials: Science and Engineering. New York: Springer; 2007.

13. Ranachowski P, Rejmund F, Ranachowski Z, Pawelek A, Piatkowski A, Kudela S Jr. Influence of microstructure on the properties of siliceous electrical porcelain. Przeglad Elektrotechniczny. 2014;10:110-113.

14. Piva DH, Piva RH, Venturini J, Ramon J, Caldas V, Morelli $\mathrm{MR}$, et al. Effect of $\mathrm{Fe}_{2} \mathrm{O}_{3}$ content on the electrical resistivity of aluminous porcelain applied to electrical insulators. Ceramics International. 2016;42(4):5045-5052.

15. Sousa FJP, das Neves WF, Alarcon OE. Study of the viability for obtaining electric insulators from enameling waste. Cerâmica. 2004;50(315):217-224.

16. Silva MA, Paes Jr HR, Holanda JNF. Reuse of ornamental rockcutting waste in aluminous porcelain. Journal of Environmental Management. 2011;92(3):936-940.

17. da Anunciação EBB. Formulação de massas cerâmicas para porcelanas elétricas utilizando resíduos oriundos de corpos de fusiveis. [Thesis]. Natal: Federal University of Rio Grande do Norte; 2013.

18. Souza GP, Sousa SJG, Terrones LAH, Holanda JNF. Mineralogical analysis of Brazilian ceramic sedimentary clays used in red ceramics. Cerâmica. 2005;51(320):382-387.

19. Okunade EA. The Effect of Wood Ash and Sawdust Admixtures on the Engineering Properties of a Burnt Laterite-Clay Brick. Journal of Applied Sciences. 2008;8(6):1042-1048.

20. Harper CA. Handbook of Ceramics, Glasses, and Diamonds. New York: McGraw-Hill; 2001.

21. Noori NR, Mamoory RS, Mehraeen S. Effect of Materials Design on Properties of Porcelain Insulators. American Ceramic Society Bulletin. 2007;86(3):9201-9205.

22. Andreola F, Barbieri L, Karamanova E, Lancelloti I, Pelino M. Recycling of CRT panel glass as fluxing agent in the porcelain stoneware tile production. Ceramics International. 2008;34(5):1289-1295.

23. Kitouni S, Harabi A. Sintering and mechanical properties of porcelains prepared from Algerian raw materials. Cerâmica. 2011;57(344):453-460.

24. Ngayakano B, Park SE. Effect of firing temperature on triaxial electrical porcelain properties made from Tanzania locally sourced ceramic raw materials. Journal of Silicate Based and Composite Materials. 2018;70(4):106-109.

25. Maslennikova GN, Orlova RG, Beshentsev VD, Bogdanis EP. Influence of feldspar on the properties of mullite electrical porcelain. Glass and Ceramics. 1984;41(10):450-452.

26. Chaudhuri SP, Sarkar P, Chakraborty AK. Electrical resistivity of porcelain in relation to constitution. Ceramics International. 1999;25(1):91-99. 